\title{
Algal Stem Blotch in Southern Highbush Blueberry in Florida'
}

\author{
Douglas Phillips, Norma Flor, and Phillip Harmon²
}

Algal stem blotch has become a significant disease on southern highbush blueberries (SHB) in Florida. It can cause stunted growth and leaf yellowing (Figure 1), as well as increased susceptibility to Botryosphaeria, in some cases leading to plant death. Information contained in this publication is intended for Florida blueberry growers to use as a guide in the identification and management of algal stem blotch on SHB.

Algal stem blotch is a blueberry disease caused by the parasitic green alga Cephaleuros virescens Kunze. Although most blueberry pathogens are fungi, $C$. virescens is a unique alga in the order Trentepohliales and the phylum Chlorophyta. The disease occurs on many cultivars of SHB (Vaccinium corymbosum) and on the native sparkleberry ( $V$. arboreum) throughout Florida. The pathogen and closely related species also cause orange cane blotch on blackberry, as well as common leaf diseases of camellia (Camellia japonica), southern magnolia (Magnolia grandiflora), and a range of tropical fruits and ornamental plants. Worldwide, C. virescens is most common in tropical and sub-tropical regions and has been recorded as a pathogen of more than 300 plant species, with at least 80 hosts suffering stem infections.

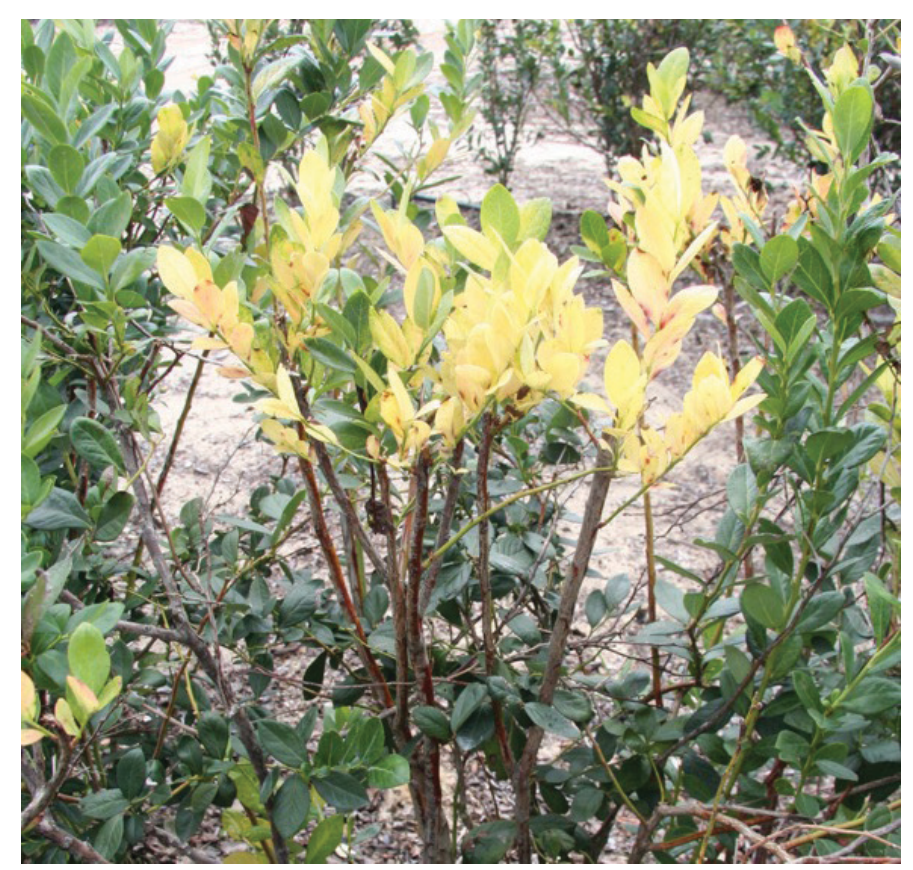

Figure 1. Plant with chlorotic leaves and stunting due to algal stem blotch infection.

Credits: P. Harmon, UF/IFAS

\section{Disease Cycle}

The alga is thought to enter the plant through natural wounds and openings, pruning cuts, or by direct penetration of the cuticle. Once inside the plant, the alga forms colonies called thalli (singular: thallus) beneath the stem cuticle and visible in red blotchy raised lesions. During hot, humid, and wet conditions, reproductive structures

1. This document is PP344, one of a series of the Plant Pathology Department, UF/IFAS Extension. Original publication date November 2018. Visit the EDIS website at https://edis.ifas.ufl.edu for the currently supported version of this publication.

2. Douglas A. Phillips, blueberry Extension coordinator, Horticultural Sciences Department; Norma C. Flor, postdoctoral researcher, Plant Pathology Department; and Philip F. Harmon, professor, Plant Pathology Department; UF/IFAS Extension, Gainesville, FL 32611. 
known as sporangiophores (Figure 2) emerge and produce zoosporangia that are wind and water splash-dispersed. Each sporangium that lands in a film of water on a blueberry cane can produce 8 to 64 swimming zoospores, also dispersed by water splash. Zoospores are the primary inoculum that initiates new infections, with peak spore production occurring roughly between May and September. Zoospore production can be very prolific, resulting in widespread and numerous summer infections. Symptom development, however, is slow, taking up to one year to produce symptoms. Plants that are stressed by abiotic or biotic factors are more susceptible to infection and subsequent disease development.

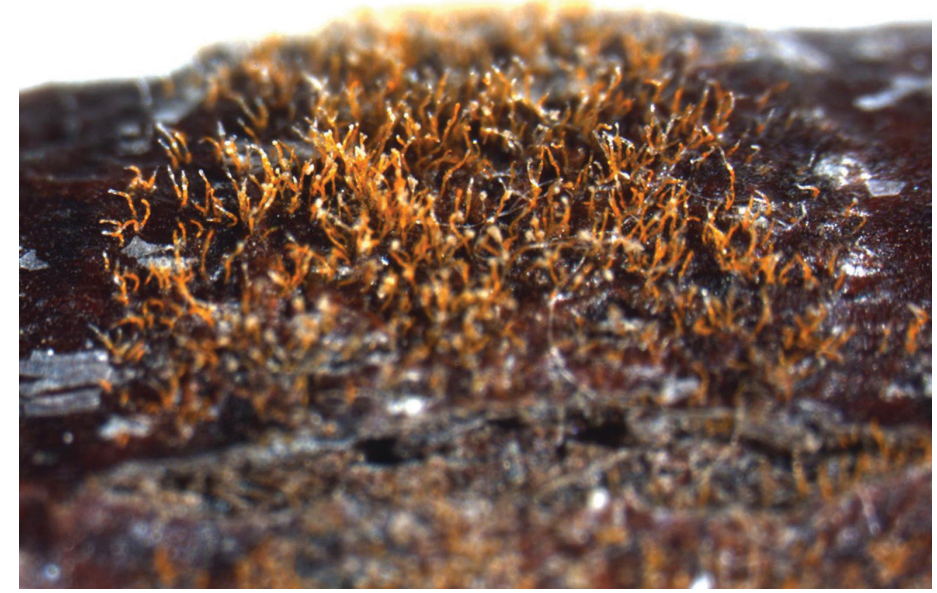

Figure 2. Sporangiophores of $C$. virescens emerging from plant tissue. Credits: N. Flor, UF/IFAS

\section{Symptoms}

Early symptoms include small red blotches or lesions on green juvenile stems. These lesions expand to form irregular cankers that can encircle canes (Figure 3). Older mature canes may not show obvious symptoms until sporulation occurs through the bark when conditions are hot and humid. Striking bright-orange felt-like mats or tufts of algal growth (sporangiophores) appear from the blotchy lesions on young stems and older cane surfaces (Figures 4 and 5). Leaves on symptomatic canes bleach white to pale yellow, and growth of the entire plant can be severely stunted as the disease advances. These symptoms are thought to be the result of the toxins delivered by the algae, although additional research is needed to confirm this hypothesis. Leaf yellowing tends to occur on a few canes of each plant and differs from symptoms of nutritional deficiency in being less uniform and blotchier (Figure 1). Defoliation also can occur with severe infections. Stunting is the result of reduction in plant vigor and can appear as a lack of regrowth after summer pruning. Eventually infected canes and stems crack, and this damaged tissue can lead to Botryosphaeria stem blight susceptibility and plant death. Although not common, leaf infections by C. virescens also can occur, with moderate defoliation in some cases (Figure 6).

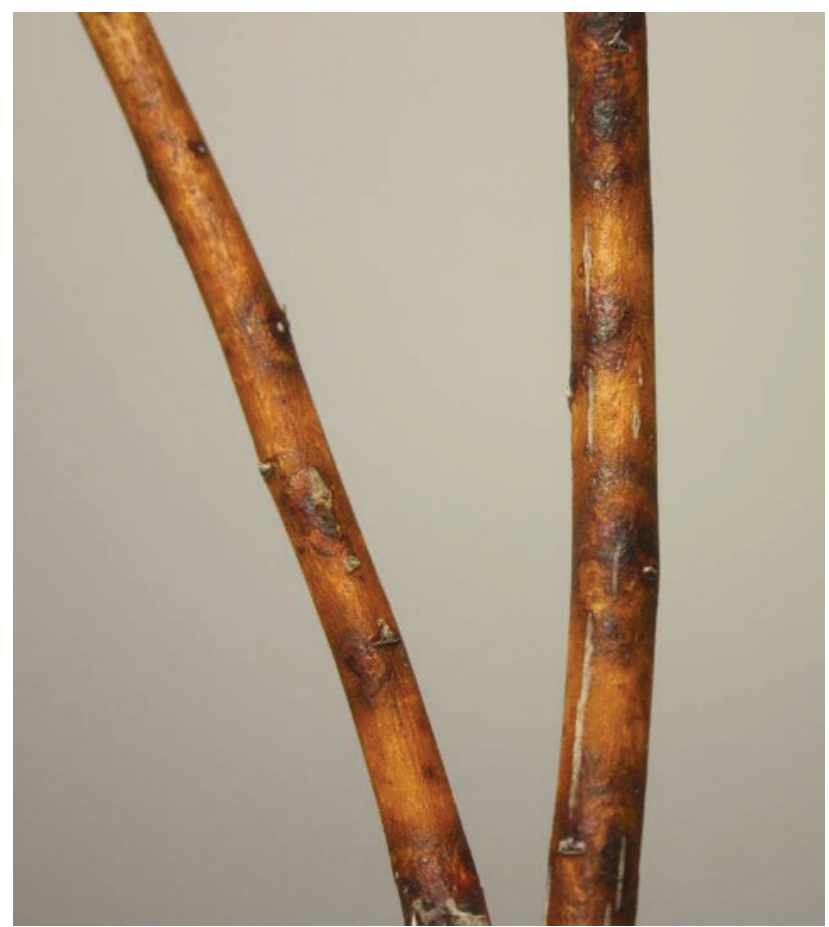

Figure 3. Algal stem blotch lesions.

Credits: P. Harmon, UF/IFAS

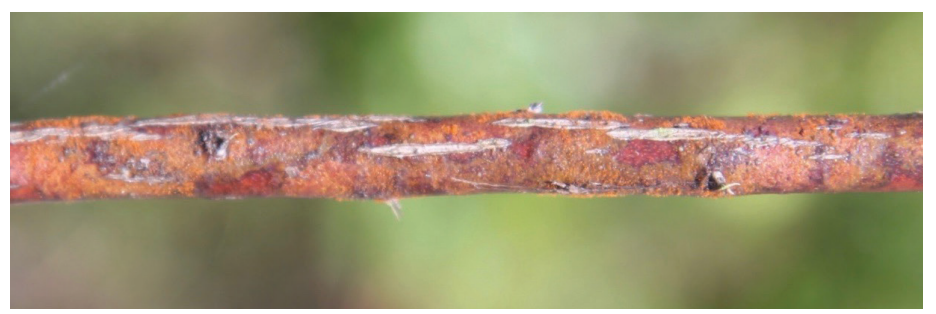

Figure 4. C. virescens reproductive structures. Credits: P. Harmon, UF/IFAS

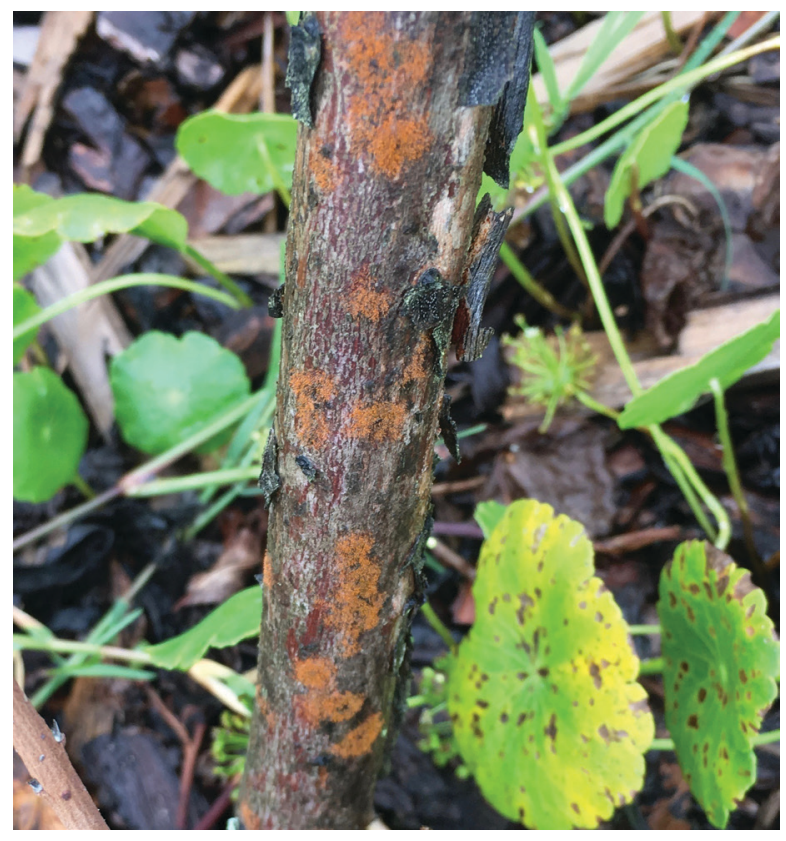

Figure 5. C. virescens reproductive structures.

Credits: D. Phillips, UF/IFAS 


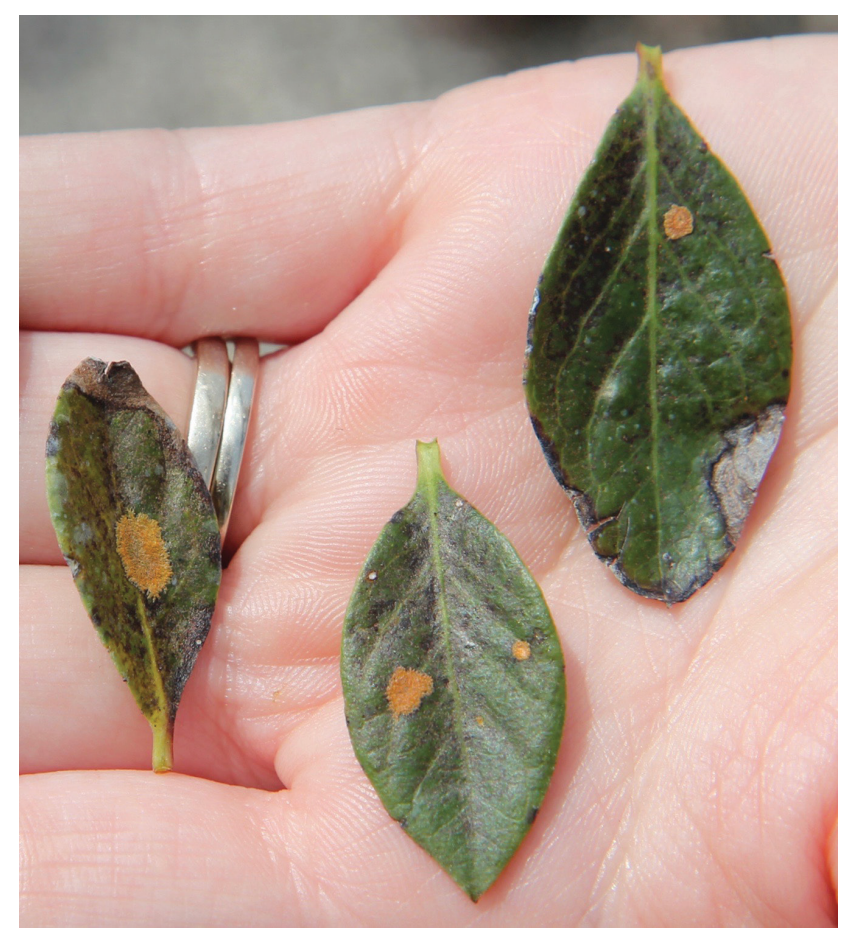

Figure 6. C. virescens reproductive structures on leaves. Credits: P. Harmon, UF/IFAS

\section{Disease Management}

Limited information exists about management practices for algal stem blotch. Most modern fungicides are specific to fungi and have no effect on algae or algal stem blotch. No systemic pesticide products have been found to date that will kill the algae living underneath the plant epidermis. Spray applications of copper-containing fungicides can help to reduce algal sporulation. These products kill the algal reproductive structures present on the plant and protect healthy canes from infection for a few days after application. However, these applications do not impact existing symptoms or eradicate the disease.

Copper product sprays should begin after harvest and continue through September. Applications must be done on a regular schedule prior to infection in order to be effective, and spray equipment must achieve good cane coverage. The specific spray schedule and rate will vary by label instruction of product chosen with reapplication intervals ranging from 7 to 28 days. More frequent applications are recommended when weather forecasts are favorable for disease development and when the disease is known to occur on the farm. Follow all label instructions and be cautious when considering tank-mixing products that contain copper with anything else. Specific issues with tank mixes of acidic products or acidifying adjuvants and copper are well-documented and can result in plant burn. Tank mixes of copper products and products with penetrants or spreader sticker type formulations also can be problematic in some conditions (Bravo Weatherstik is an example). For specific product rates, timings, and details, see the UF/IFAS Blueberry Integrated Pest Management Guide (http://edis. ifas.ufl.edu/pdffiles/HS/HS38000.pdf).

Certain cultural practices also can help reduce the spread of disease. Disease-free stock should be used for new plantings. Good management practices (irrigation, fertilization, sanitation, and disease and pest control) will reduce plant stress and help the plants be less susceptible to disease. Overhead irrigation should be avoided if possible when disease is present because it favors the spread of algal reproductive structures. In addition, removing and destroying infected canes and eliminating weeds improves air circulation in the canopy and can help to slow disease development. Disinfection of pruning equipment where symptoms are present may also help minimize the spread of disease.

\section{References}

Browne, F. B., L. A. Fall, P. M. Brannen, J. Taylor, J. Shealey, and E. D. Beasley. 2016. "Assessment of algicides, disinfectants and fungicides for control of orange cane blotch caused by the alga Cephaleuros virescens." Acta Hortic. 1133: 497-502.

Nelson, S. C. 2008. "Cephaleuros species, the Plant-Parasitic Green Algae”. PD-43. Univ. Hawaii Coop. Ext. Serv. Honolulu, HI.: 6 pp.

Vasconcelos, C.V., F. T. Pereira, E. A. A. Duarte, T. A. S. de Oliveira, N. Peixoto, and D. D. C. Carvalho. 2018. Physiological and Molecular Characterization of Cephaleuros virescens Occurring in Mango Trees. plant Pathol. J. 34(3): 157-162.

Vasconcelos, C. V., F. T. Pereira, C. dos S. Galvão, D. D. C. Carvalho, C. V. Vasconcelos, F. T. Pereira, C. dos S. Galvão, and D. D. C. Carvalho. 2016. "Occurrence of algal leaf spot (Cephaleuros virescens Kunze) on avocado in Goiás State, Brazil." Summa Phytopathol. 42(1): 108-108.

Williamson, J. G., P. F. Harmon, O. E. Liburd, and P. Dittmar. 2019 Florida Blueberry Integrated Pest Management Guide. HS1156. Gainesville: University of Florida Institute of Food and Agricultural Sciences. http://edis.ifas.ufl.edu/ hs 380 